\title{
Czy metodologia powinna zaćmiewać faktografię? Nowe spojrzenie na rewolucję 1905 roku*
}

Zarys treści: Artykuł stanowi polemikę z założeniami, które w swojej pracy Rebelia i reakcja. Rewolucja 1905 roku i plebejskie doświadczenie polityczne zaprezentował Wiktor Marzec. Będąca niewątpliwie nowym głosem w dyskusji nad problematyką rewolucyjnych wydarzeń początku $\mathrm{XX}$ w. pozycja, zdaniem autora, jest przesycona anglosaską metodologią, nie wnosząc nowych faktograficznych ustaleń do literatury przedmiotu. Skupienie się na wyrywkowych fragmentach rewolucji roku 1905 oraz ignorowanie niektórych sił społeczno-politycznych nie wystarcza do omówienia plebejskiego doświadczenia politycznego oraz do całościowego opisu polskiej nowoczesności politycznej.

Outline of content: The article is a polemics with theses presented in the book by Wiktor Marzec Rebelia i reakcja. Rewolucja 1905 roku i plebejskie doświadczenie polityczne [Rebellion and Reaction. The 1905 Revolution and Plebeian Political Experience]. Undoubtedly, the book which is a new and interesting voice in the discussion of problems of revolutionary events at the beginning of the $20^{\text {th }}$ century, according to the reviewer, is imbued with Anglo-Saxon methodology, and does not add any new factual contribution to the literature on the subject. Focusing on random fragments of the 1905 Revolution and ignoring certain socio-political forces is not enough to discuss the plebeian political experience and to give a comprehensive description of Polish political modernity.

Słowa kluczowe: rewolucja 1905 roku, Królestwo Polskie, Imperium Rosyjskie, gubernia grodzieńska, socjalizm, Bund, anarchizm, Narodowa Demokracja

Keywords: Revolution of 1905, Kingdom of Poland, Russian Empire, Grodno Governorate, socialism, Bund, anarchism, National Democracy

* W. Marzec, Rebelia i reakcja. Rewolucja 1905 roku i plebejskie doświadczenie polityczne, KrakówŁódź 2016. Artykuł powstał w ramach projektu badawczego „Rewolucja 1905 roku w guberni grodzieńskiej. Oblicze ideowe a wymiar praktyczny” (grant FUGA 4, NCN: Nr DEC-2015/16/S/ HS/00532). 
Piotr Laskowski swoją najnowszą pracę poświęconą Janowi Wacławowi Machajskiemu i jego poglądom na sprawę robotniczą zaczął od słów: „Na początku jest głód"'. Od głodu klas uboższych zaczyna się droga ku rewolucji. Nieco parafrazując warszawskiego filozofa, można powiedzieć, iż podobnie jest $\mathrm{z}$ badaniami historycznymi. Głód, który mam na myśli, dotyczy polskich badań nad zagadnieniami związanymi z szeroko pojętym nurtem robotniczym, radykalnymi nurtami lewicowymi, a zwłaszcza epoką, kiedy owe ruchy odgrywały szczególną rolę w życiu społeczno-politycznym olbrzymiego terytorium - Imperium Rosyjskiego, częścią którego było Królestwo Polskie. Głód badań tego okresu, który odczuwają przeważnie badacze młodego pokolenia, jest częściowo spowodowany przesyceniem historiografią robotniczą i rewolucyjną z okresu PRL. Wydaje się, że z tezą, iż wydarzenia $\mathrm{z}$ tamtego okresu zostały niejako zapomniane i odsunięte na dalszy plan we współczesnej polskiej historiografii, zgodzi się większość historyków². W ostatnim dziesięcioleciu, łącznie z tekstami źródłowymi, ukazało się zaledwie 10 pozycji poświęconych owemu zagadnieniu ${ }^{3}$. Z tego powodu, jako badacz zajmujący się m.in. problematyką rewolucji 1905 roku, z entuzjazmem przyjąłem wiadomość o pojawieniu się na rynku wydawniczym nowej pozycji na ten temat.

1 J.W. Machajski, Pracownik umysłowy i inne pisma, wprow. i red. nauk. P. Laskowski, Warszawa 2016, s. 7.

2 Zob. А.И. Ланевский, Актриса второго плана: память о революиии 1905-1907 г2. в Польше, w: 80 лет Великой Испанской революиии: память, люди, уроки (Прямухинские чтения 2016), ред. С.Г. Корнилов [и др.], Москва 2017, s. 189-217. M.in. ubolewają nad tym wspomniany wyżej warszawski filozof Piotr Laskowski: Rewolucja 1905 r. - dlaczego rewolucja została zapomniana? W Ogrodzie Powszechnym rozmawiaja prof. Piotr Laskowski i Karolina Lewicka, https:// audycje.tokfm.pl/podcast/Rewolucja-1905-r-dlaczego-rewolucja-zostala-zapomniana-W-Ogrodzie-Powszechnym-rozmawiaja-prof-Piotr-Laskowski-i-Karolina-Lewicka/64201 (dostęp: 1.10.2018), czy znany polski dziennikarz Edwin Bendyk: idem, Oburzeni 1905. Zapomniana rewolucja $z$ poczatku XX w., https://www.polityka.pl/tygodnikpolityka/historia/1622495,2,zapomniana-rewolucja-z-poczatku-xx-w.read (dostęp: 1.10.2018). 23 VI 2017 r. w Muzeum Tradycji Niepodległościowych w Łodzi odbyła się debata historyków pt. „Rewolucja 1905 - historia (nie)zapomniana”, https://www.youtube.com/watch?v=NytVdUKQjKA (dostęp: 1.10.2018).

${ }^{3}$ N. Giter-Granatsztajn, Barykady i katorga. Wspomnienia anarchisty, Poznań 2015; M. Sikorska-Kowalska, „Wolność czy zbrodnia?” Rewolucja 1905-1907 roku w Łodzi na łamach gazety „Rozwój”, Łódź 2012; I. Boerner, Pamiętnik z lat 1904-1905 (wraz z załącznikami), red. T. Karbowniczek, Piotrków Trybunalski 2011; T. Bogalecki, Łódzkie barykady wolności i godności: czerwiec 1905 roku, Łódź 2010; R. Luksemburg, O rewolucji: Rosja 1905, 1917, red. P. Wielgosz, Warszawa 2008; W. Potkański, Odrodzenie czynu niepodległościowego przez PPS w okresie rewolucji 1905 roku, Warszawa 2008; B. Szabat, Kielce i kielczanie w czasie rewolucji 1905-1907 roku, Kielce 2009; K.R. Kowalczyński, Łódź 1905. Kulisy rewolucji, Łódź 2017. Wśród artykułów należy wyróżnić: A. Żarnowska, Spojrzenie na rewolucje 1905 r. w polskiej historiografii - garść refleksji, „Kwartalnik Historyczny" 63 (2006), nr 4, s. 59-94; A. Szwarc, Rewolucja 1905 roku na ziemiach polskich. Refleksje o historiografii i postawach inteligenckich elit, „Artes Liberales. Zeszyty Naukowe Wyższej Szkoły Humanistycznej im. Aleksandra Gieysztora” (2006), nr 1, s. 25-36; popularnonaukowe czasopismo „Mówią Wieki” (2015), nr 1 - numer poświęcony rewolucji 1905 roku. Na marginesie można odnotować również powieść: W. Holewiński, Pogrom 1905, Poznań 2018. 
Najnowsza rozprawa tym bardziej wydawała się interesująca, gdyż jest to debiut książkowy młodego badacza z Łodzi ${ }^{4}$.

Wiktor Marzec (ur. 1985), z wykształcenia socjolog i filozof, zajmuje stanowisko redaktora działu „Krytyczne nauki społeczne” w czasopiśmie naukowym „Praktyka Teoretyczna" ". Marzec jest dość płodnym i ambitnym badaczem, jego artykuły ukazywały się m.in. w „Politeji”, „Polish Sociological Review”, „East European Politics and Societies and Culture”, "Journal of Historical Sociology” i in. Przebywał na stypendiach w USA i Niemczech, fakt ten niewątpliwie wpłynął na formę książki, wydanie której było wynikiem finansowanego ze środków Narodowego Centrum Nauki projektu realizowanego w Instytucie Socjologii Uniwersytetu Łódzkiego. Do zainteresowań naukowych Marca należą socjologia historyczna oraz historia robotnicza. W 2017 r. na Wydziale Socjologii i Antropologii Społecznej Uniwersytetu Środkowoeuropejskiego w Budapeszcie (CEU) obronił rozprawę doktorską poświęconą mobilizacji politycznej i emancypacji intelektualnej robotników w okresie rewolucji 1905 roku$^{6}$.

Nie jest to pierwsze zmierzenie się Autora z tematyką rewolucji 1905 roku. Oprócz wcześniejszych swoich artykułów łódzki badacz wraz z Kamilem Piskałą redagował książkę Rewolucja 1905 roku. Przewodnik Krytyki Politycznej ${ }^{7}$. Ponadto Marzec zajmuje się popularyzacją historii, jest związany ze środowiskiem aktywistów komemoracyjnych z łódzkiej inicjatywy „Rewolucja 1905 roku”. Był również konsultantem wydanej pod koniec 2016 r. gry karcianej „Rewolucja 1905 roku"'.

Recenzowana praca ukazała się w zapoczątkowanej w 1997 r. serii wydawniczej „Horyzonty Nowoczesności” krakowskiego wydawnictwa Universitas we współpracy z Wydawnictwem Uniwersytetu Łódzkiego. Recenzentami byli prof.prof. Jan Sowa i Tomasz Kizwalter ${ }^{10}$. Monografia spotkała się ze stosunkowo dużym zainteresowaniem czytelników, przede wszystkim ze środowisk lewicowych ${ }^{11}$. Pojawiło się

${ }^{4}$ Co prawda Autor był już redaktorem kilku pozycji, ale recenzowana książka jest jego pierwszą samodzielną monografią.

5 „Praktyka Teoretyczna”, http://www.praktykateoretyczna.pl/ (dostęp: 1.10.2018).

${ }^{6}$ Publikacje W. Marca są dostępne na jego profilu w serwisie Academia: https://hse-ru.academia. edu/WiktorMarzec (dostęp: 1.10.2018).

7 Rewolucja 1905 roku. Przewodnik Krytyki Politycznej, red. K. Piskała, W. Marzec, Warszawa 2013.

${ }^{8}$ Rewolucja1905.pl (dostęp: 1.10.2018).

9 Jej szczegółowe krytyczne omówienie: Raleen, Rewolucja 1905 (Krytyka Polityczna \& Departament Gier), http://portal.strategie.net.pl/index.php?option=com_content\&view=article\&id=2744:rewolucja-1905-krytyka-polityczna-a-departament-gier\&catid=20:recenzje-gier-planszowych\&Itemid=119 (dostęp: 1.10.2018).

10 Skrócona wersja ukazała się w: T. Kizwalter, Zapomniana rewolucja i jej kłopotliwe skutki. O książce „Rebelia i reakcja” Wiktora Marca, http://kulturaliberalna.pl/2017/04/04/marzec-rebelia-reakcja-recenzja-kizwalter/ (dostęp: 5.04.2018).

${ }_{11}$ M.in. na portalu lewica.pl można było na nią zagłosować, jako na najlepszą polską lewicową książkę wydaną w 2016 r. 
kilka internetowych recenzji publicystycznych, a krótka recenzja prof. Przemysława Waingertnera ukazała się w kwartalniku „Kronika Miasta Łodzi”12. Interesująca recenzja politologiczna pracy powstała także na Uniwersytecie Opolskim ${ }^{13}$. Recenzje ukazały się również w prestiżowych „Kwartalniku Historycznym” oraz „Slavic Review"14. Prezentacja Rebelii i reakcji oraz spotkania dyskusyjne wokół książki odbyły się w różnych miastach Polski, w tym na uczelniach (Warszawa, Łódź, Poznań, Kraków, Katowice i in.). Omówienie tej pozycji miało miejsce także na spotkaniu Zakładu Historii XX Wieku Instytutu Historii im. Tadeusza Manteuffla PAN w Warszawie, czego pokłosiem, a zarazem krytycznym głosem w dyskusji z pozycji warsztatu historyka jest niniejszy artykuł recenzyjny.

Książka składa się z „Wprowadzenia, 3 zasadniczych części: „Rebelia”, „Rewolucja”, „Reakcja”, oraz „Zakończenia”. W monografii zostało ponadto zamieszczone streszczenie (w języku angielskim), wykaz skrótów, omówienie bazy źródłowej oraz indeks nazwisk (przy braku indeksu miejscowości). Ze względu na to, że rozwój politycznego doświadczenia robotników, dynamika procesu politycznego i rozwój zaplecza filozoficznego cechuje inny rytm, zdaniem Autora, postanowił on zastosować w każdym rozdziale własną chronologię.

Już sam tytuł rozprawy budzi pewne zastrzeżenia. Wiktor Marzec nie zaznacza obszaru geograficznego rewolucji. Pamiętajmy, że „rewolucja 1905 roku” to też pierwsza rosyjska rewolucja 1905-1907. Wydarzenia te obejmowały ogromny, mieszczący się w granicach jednego imperium teren i nie zawsze praktyka-rebelia, jak też praktyka-reakcja były tożsame dla różnych obszarów państwa Romanowów. Zabrakło u Autora doprecyzowania "Królestwo Polskie"15. Wskazując na „warszawocentryczność” polskiej historii intelektualnej, „współdzielącej z nimi [podmiotami badawczymi] pole niewidzialności” (s. 42), Marzec mówi, że prezentuje spojrzenie spoza Warszawy - z Łodzi, gdzie, jak podkreśla, już wcześniej powstały pewne nowatorskie nurty badawcze (emancypacja kobiet w rewolucji, nowoczesność i postęp w prasie prowincjonalnej, rewolucja jako powstanie miejskie, doświadczenie miejskiej nowoczesności itd.). Sam Autor twierdzi, że to nie jest książka o mieście (rzeczywiście brakuje przykładów praktyki rewolucyjnej w przestrzeni miejskiej) i nie jest o Łodzi, chociaż w porównaniu z pojawiającymi się zaledwie w tle Zagłębiem Dąbrowskim i Warszawą na pierwsze miejsce wysuwa się „Polski

12 P. Waingertner, Najnowsza książka Wiktora Marca. Socjolog, filozof i historyk o rewolucji 1905 roku, „Kronika Miasta Łodzi” (2016), nr 4 (76), s. 199-203.

13 M. Ozimek, Wyobraźnia teoriopolityczna. Kilka uwag na marginesie ksią̇̇ki Rebelia i reakcja. Rewolucja 1905 roku i plebejskie doświadczenie polityczne Wiktora Marca, „Society Register” (2017), nr 1, s. 167-181.

${ }^{14}$ M. Micińska, Wiktor Marzec, Rebelia i reakcja. Rewolucja 1905 roku i plebejskie doświadczenie polityczne [recenzja], „Kwartalnik Historyczny” 125 (2018), nr 3, s. 779-782; T. Weeks, Rebelia i reakcja: Rewolucja 1905 roku i plebejskie doświadczenie polityczne. By Wiktor Marzec [recenzja], „Slavic Review” (2017) no. 4(76), s. 1082-1083.

15 Doprecyzowanie to znalazło się jedynie w angielskim streszczeniu książki pt. Rebellion and Reaction. The 1905 Revolution in Russian Poland and Plebeian Political Experience (s. 505). 
Manchester". Niemniej jednak - jak zobaczymy niżej - Autor nieraz sam wpada w pułapkę „łódzkocentryczności”, która niewiele różni się od krytykowanej przez niego stołecznej. Szkoda, że Autor ominął Białostocki Okręg Przemysłowy z niezwykle ważnym dla badań nad rewolucją 1905 roku miastem - „Manchesterem Północy”. Białystok, jedna ze „stolic” anarchizmu w Imperium Rosyjskim, był ideową „ojczyzną” Związku Socjalistów-Rewolucjonistów Maksymalistów, ogniskiem krzyżującej się działalności polskich, rosyjskich i żydowskich partii rewolucyjnych, przeżywszy dwa pogromy żydowskie i stan wojenny. $\mathrm{Z}$ tego powodu jako odniesienie do rozważań Marca kilkakrotnie wykorzystam bezpośrednio graniczącą z Królestwem Polskim gubernię grodzieńską ${ }^{16}$. Taki zabieg można zakwestionować przywołaniem faktu, iż gubernia grodzieńska znajdowała się poza granicami Kraju Nadwiślańskiego, a wpływy Narodowej Demokracji były znikome ${ }^{17}$. Na jego obronę można natomiast przytoczyć kilka argumentów. Przede wszystkim, pisząc o reakcji, Autor sam wybiega poza granice Królestwa Polskiego, pozostawiając przy tym narrację o robotnikach w jej granicach. Po drugie, Autor zdaje się świadomie (s. 32) wyrywkowo potraktował temat: socjaliści $v$ s endecja (rodzima polska reakcja), nie uwzględniając tak wielkiego wachlarza sił reakcyjnych (np. organizacje czarnosecinne i syjonistyczne), które wpływały na kształtowanie nowoczesnej polityki, w tym polskiej. Wzmiankuje tylko o liberalnej inteligencji jako o sile reakcyjnej po rewolucji. Ponadto w guberni grodzieńskiej również działały polskie partie polityczne: PPS, PPS Proletariat, SDKPiL, ale też nieobecny w książce Bund, anarchiści oraz syjoniści, których Autor także nie uwzględnił w swoich rozważaniach, zwłaszcza w ostatniej części.

Rebelia i reakcja jest po części próbą interwencji w bieżącą dyskusję o klasach czy społeczeństwie obywatelskim, przywracając myśleniu Polaków opowieści o stosunkach klasowych („Historia społeczeństw jest również historią walk klasowych”, s. 14). Taka postawa wiąże się nie tylko z tematem pracy, ale również z poglądami samego badacza. Według wypowiedzianych w jednym z wywiadów słów Wiktora Marca: „praca nie jest może radykalnie lewicowa, ale jednak dość wyraźnie wpisuje się w światopogląd socjaldemokratyczny" ${ }^{\prime 8}$. Już na początku łódzki badacz artykułuje, że należy do tego samego nurtu, co i jego recenzent Jan Sowa ${ }^{19}$, przy

${ }^{16} \mathrm{~W}$ raportach do grodzieńskiego gubernatora brzeski policmajster A. Sokołow 20 VI $1907 \mathrm{r}$. stwierdzał, że Brześć związany jest z Białą Podlaską, Siedlcami i Warszawą, dlatego „całkowicie żyje życiem owego kraju”, gdzie ponownie narasta ruch rewolucyjny, Нацыянальны гістарычны архіў Беларусі ў г. Гродна (НГАБ у Гродне), f. 366, op. 1, d. 95, k. 645-646.

17 Zob. P. Dobrowolski, Narodowa Demokracja byłego Wielkiego Księstwa Litewskiego: studium z zakresu myśli politycznej i działalności obozu narodowego na ziemiach litewsko-białoruskich w latach 1897-1918, Kraków 2010.

18 Polityczność plebsu. Z Wiktorem Marcem, autorem książki Rebelia i reakcja. Rewolucja 1905 roku i plebejskie doświadczenie polityczne, rozmawia Magda Roszkowska, „Notes na 6 Tygodni” (2016/2017), nr 109, s. 81-89.

19 J. Sowa, Fantomowe ciało króla. Peryferyjne zmagania z nowoczesna formą, Kraków 2011; idem, Inna Rzeczpospolita jest możliwa! Widma przeszłości, Warszawa 2014. 
tym wyraźnie zaznaczając, iż sprzeciwia się liberalnemu badaczowi, odmawiającemu podmiotowości tego rodzaju polskiemu ludowi ${ }^{20}$. Rewolucja jako przełom przyśpieszający wejście polskiego społeczeństwa w polityczną nowoczesność jest pojmowana przez Autora jako „zestaw politycznych korelatów procesu modernizacji w rozumieniu typowym raczej socjologii, takich jak demokratyzacja życia publicznego, zanik heteronomicznego porządku uzasadnienia i nowe, bardziej inkluzyjne imaginaria społeczne" (s. $17 \mathrm{nn}$.). Marzec usiłuje pokazać, w jaki sposób kształtowała się polska sfera publiczna, dla której rewolucja 1905 roku stanowiła wydarzenie kluczowe, ustanawiając filary nowoczesności, oraz zmieniając układ sił pomiędzy różnymi grupami i klasami. Jego zdaniem, właśnie na początku XX w. po raz pierwszy duża część społeczeństwa wywalczyła sobie miejsce w sferze publicznej, a wyznaczone poszczególnym grupom w przestrzeni politycznej „pozycje” $\mathrm{w}$ dużym stopniu utrzymują się do dzisiaj. $\mathrm{Z}$ tego powodu, w opinii Marca, jest to książka o nowoczesności, gdyż mamy do czynienia $\mathrm{z}$,wyparciem doświadczenia nowoczesności z polskiej tożsamości i wyobrażonej osi czasu" (s. 40).

Według słów socjologa, temat, który podjął, został wyparty przez prawicową historiografię i zmianę ustrojową, a jego analiza jest „częścią nurtu rewizjonistycznych prac reinterpretujących wydarzenia czy procesy polskiej historii" (s. 39). Za cel uznaje zatem „przywrócenie historiograficznej widzialności plebsu”, czyli tych, dla których zabrakło miejsca w historii elitarnej, w przypadku Polski - w historii narodowej. Rewolucja 1905 roku stanowi dobitny przykład tego, że perspektywa odbierania ludu jako przedmiotu historii narodowej pozbawia możliwości zrozumienia rzeczywistej złożoności charakteryzującej historię społeczną, uważa Autor ${ }^{21}$.

Trudno nie zgodzić się z Autorem, że temat rewolucji 1905 roku został porzucony i że brakuje prac „w świetle nowych podejść teoretycznych i metodologicznych” (s. 63 nn.), tylko czy taki stan rzeczy jest bezpośrednio związany z „oczywistym prawicowym zwrotem polskiej historiografii” po 1989 r. (s. 39)? Ten sąd wydaje się być pewnym uproszczeniem, gdyż każda epoka (władza) dyktuje modę na inne perspektywy badawcze ${ }^{22}$. Wydaje się jednak, że kwestie antagonizmów

20 A. Leder, Prześniona rewolucja. Ćwiczenia z logiki historycznej, Warszawa 2014.

${ }^{21}$ Przedwczesnymi okazały się wypowiedziane ponad 20 lat temu słowa Jana Kancewicza o tym, że: „Stadium idealizacji proletariatu mamy już chyba za sobą”, idem, „Społeczeństwo i polityka - dorastanie do demokracji. Kultura polityczna w Królestwie Polskim na początku XX wieku", red. Anna Żarnowska, Tadeusz Wolsza, Warszawa 1993 [recenzja], „Przegląd Historyczny” 85 (1994), nr 4, s. 503.

22 Autor zdaje się nie uwzględniać swoistego „boomu” na nowe podejścia metodologiczne, m.in. teorie Haydena White'a i Franka Ankersmita, szeroko popularyzowane w Polsce w erudycyjnych pracach poznańskiej badaczki Ewy Domańskiej, zob. eadem, Historie niekonwencjonalne. Refleksja o przeszłości w nowej humanistyce, Poznań 2006; eadem, Historia egzystencjalna. Krytyczne studium narratywizmu i humanistyki zaangażowanej, Warszawa 2012, i in. Wśród przykładów „nienarodowej” historii można wymienić stosunkowo spory dorobek „herstory”: M. Ciechomska, Od matriarchatu do feminizmu, Poznań 1996; M. Bogucka, Gorsza pleć. Kobieta w dziejach Europy od antyku po wiek XXI, Warszawa 2005; A. Mrozik, Akuszerki transformacji. Kobiety, 
klasowych, a wraz z nimi i złożona problematyka rewolucji 1905 roku, zwłaszcza $\mathrm{w}$ coraz bardziej spolaryzowanym i niestabilnym świecie, jeszcze powróci do problematyki badawczej polskich historyków.

Historykom, odwołującym się do tradycji pozytywistycznej, książka młodego badacza może nie przypaść do gustu. Omawiana pozycja nie jest książką stricte historyczną (s. 46), brak w niej nowych ustaleń faktograficznych i uchwycenia szerszego wachlarza czynników. Jest to raczej reinterpretacja ówczesnych wydarzeń, w której „narracja czysto historyczna niejednokrotnie ustępuje miejsca obserwacji socjologa i refleksji filozofa"23. Jest to studium interdyscyplinarne, co stawia przed autorem ogromne wyzwania. Głównym przedmiotem uwagi są dyskursy polityczne (s. $15 \mathrm{nn}$.), a swoje badania Marzec nazywa „ludową/plebejską historią intelektualną", albo „socjologią historyczną tego, co polityczne” (s. 46).

I w tym, moim zdaniem, tkwi pewien paradoks: Marzec zabiera głos w obronie plebsu, ale studiując monografię, odnosi się wrażenie, że monografia powstała nie dla ogółu, nie dla bohatera tej pracy - plebsu, lecz dla wąskiego grona filozofów, historyków i socjologów, słowem, intelektualistów, którzy dyskutują o podobnych pozycjach w swoim często ekskluzywnym świecie. Zdaję sobie sprawę, że osobom $\mathrm{z}$ brakiem osadzenia $\mathrm{w}$ socjologii historycznej i filozofii politycznej będzie niezmiernie trudno o łatwy odbiór zawartej w pracy informacji. Możliwe, że do tych osób należy również autor tych słów, i dlatego, moim zdaniem, recenzowana książka daleka jest od tego, żeby się dawała czytać z zapartym tchem ${ }^{24}$. Monografia jest przeładowana naukową terminologią i odwołaniami do anglosaskiej literatury przedmiotu $^{25}$. W trakcie lektury odnosi się wrażenie nagromadzenia metodologii, wypychającej na dalszy plan skonfrontowanie źródeł i rzeczywistą pracę z nimi.

literatura $i$ władza $w$ Polsce po 1989 roku, Warszawa 2012; N. Jarska, Kobiety z marmuru. Robotnice $w$ Polsce $w$ latach 1945-1960, Warszawa 2015 (wydane przez IPN!); M. Dzido, Kobiety Solidarności, Warszawa 2016.

23 P. Waingertner, Najnowsza ksiązka Wiktora Marca..., s. 200.

${ }^{24}$ Co idzie wbrew twierdzeniu, że socjologia historyczna „zyskuje na atrakcyjności pewnie i dlatego, że nie jest nauką społeczną w obiegowym rozumieniu; nie opisuje banalnych zjawisk za pomocą niezrozumiałego języka. W warstwie językowej sytuuje się blisko klasycznej historiografii, przez co owocnie czerpie, przez co jej teksty zbliżają się do opisów literackich”, B. Cymbrowski, K. Frysztacki, Socjologowie patrzq wstecz. Socjologia historyczna między teoriq społeczna a splotem subdyscyplin szczegółowych, w: Socjologia historyczna. Wokół wyzwań i praktyki badawczej, red. iidem, Opole 2015, s. 14; zob. też interesujące rozważania o złożonych relacjach historyków i socjologów, różnicy celów, warsztatów, oczekiwań odbiorców, ograniczeniach itd.: M. Kula, Historycy a socjologowie dziś, ibidem, s. 21-30; B. Cymbrowski, Od historyzmu do socjologii historycznej. Szkic o metodologii, ibidem, s. 61-78.

25 Np. w przypisie do literatury na temat I Proletariatu (s. 240 nn.) Marzec podaje dwie anglojęzyczne monografie, zapominając o polskich badaniach: Kółka socjalistyczne, gminy $i$ Wielki Proletariat. Procesy polityczne 1878-1888. Źródła, oprac. i wstęp L. Baumgarten, Warszawa 1966; idem, Dzieje Wielkiego Proletariatu, Warszawa 1966; I. Koberdowa, Socjalno-Rewolucyjna Partia Proletariat, Warszawa 1981. Zasadne wydaje się tu pytanie: czy niedługo będziemy uczyć się historii Polski z obcych podręczników? 
Czy jednym z zadań inteligenta, którym jest Autor recenzowanej rozprawy, nie jest wyjaśnienie wielowymiarowego świata prostymi słowami, a nie odwrotnie komplikowanie rzeczy prostych ${ }^{26}$ ?

Redaktor „Praktyki Teoretycznej” wychodzi z założenia o chłopskich korzeniach Polaków i słabych związkach z miastem w ich świadomości historycznej, dlatego kształt naszego życia zawdzięczamy podstawowemu podmiotowi politycznemu XIX w. - proletariatowi, ale też masowo migrującym do miast chłopom ${ }^{27}$. Jeden ze stawianych Autorowi zarzutów dotyczy braku chłopów w jego narracji o rewolucji 1905 roku. Marzec broni się, iż ta książka nie jest o chłopach, chociaż, według mnie, powinni się w niej znaleźć. Być może właśnie chłopi przeżywali wówczas największe przejście do nowoczesności ${ }^{28}$. Zdaniem rosyjskiego historyka Olega Buchowca rewolucja 1905 roku była niezmiernie ważna właśnie dla chłopów. Prigowory i nakazy włościańskie były niczym innym jak elementem demokratyzacji chłopów ${ }^{29}$. W obszernej bibliografii u Marca, składającej się z literatury przedmiotu w językach: angielskim, niemieckim i polskim, nie doszukałem się prac autorów rosyjskich ${ }^{30}$. Oczywiście żaden badacz nie jest w stanie uwzględnić całości materiału, ale w wypadku pierwszej rosyjskiej rewolucji można się o to pokusić. Autor pominął m.in. poświęconą chłopom ważną pracę z zakresu

${ }^{26}$ Pozwolę sobie przytoczyć wypowiedź Jerzego Damrosza: „Wyniki obserwacji mówiących i piszących pracowników naukowych z zakresu humanistyki, urodzonych nie wcześniej niż w trzecim ćwierćwieczu XX wieku, wskazują na dość częstą dążność dostosowania języka hermetycznego i powierzchownego naśladowania poglądów zachodnioeuropejskich i angloamerykańskich, czyli unikania jasności w formułowaniu własnych myśli. Młodzież wykształcona tym bardziej niechętnie sięga do takich publikacji [...]. W publikacjach naukowych - obok oczywiście koniecznych badań i ekspertyz specjalistycznych - powinno się uwzględniać zrozumiałe dla szerszego kręgu odbiorców zasoby wiedzy wraz z odpowiednią interpretacją", Świat należy nie tylko objaśniać, ale i przekształcać... Rozmowa z profesorem dr. hab. Jerzym Damroszem, „Rocznik Towarzystwa Naukowego Płockiego" (2014), nr 6, s. 496.

27 Tezę o słabych więziach Polaków z miastem potwierdzają wywody zawarte w interesującej książce krakowskiego socjologa: P. Kubicki, Wynajdywanie miejskości, Kraków 2016.

28 J. Gmitruk, Ruch ludowy w okresie rewolucji 1905 roku, w: Dziedzictwo rewolucji 1905-1907, red. A. Żarnowska [i in.], Warszawa-Radom 2007, s. 117-131; A. Wójcik, Wpływ partii politycznych na kształtowanie świadomości społecznej i narodowej na Lubelszczyźnie na przełomie XIX i XX wieku, „Acta Universitatis Lodziensis. Folia Historica” (1992), nr 45, s. 111-118.

29 Zob. О.Г. Буховец, Социальные конфликты и крестьянская ментальность в Российской империи начала ХХ века. Новые материаль, методы, результаты, Москва 1996.

${ }^{30} \mathrm{~W}$ ostatnich latach rosyjska literatura przedmiotu wzbogaciła się przynajmniej o kilka wartościowych pozyсji: С. Павлов, Опыт первой революиии. Россия. 1900-1907, Москва 2008; Россия в 1905-1907 г2.: энциклопедия, отв. ред. В.В. Журавлев [и др.], Москва 2016 (w tej fundamentalnej pracy hasło Польский вопрос autorstwa Aleksandry Bachturin zajmuje nieco ponad trzy strony, s. 734-738); Власть и общество в Первой российской революиии 1905-1907 г2. Документальные свидетельства, сост., ред. и предисл. А.П. Ненароков, П.Ю. Савельев, отв. ред. А.А. Чернобаев, Москва 2017. Рo raz pierwszy od stu lat wydano też pracę czołowego polskiego narodowca: Р. Дмовский, Германия, Россия и польский вопрос, ред. Д.С. Буневич, Г.В. Холодов, пер. с пол. А.Ю. Баженова, Санкт-Петербург 2017. 
socjologii historycznej autorstwa urodzonego w 1930 r. w Wilnie Teodora Shanina ${ }^{31}$. Omawiana książka, mówi Autor, nie jest także o inteligencji. Teoretycznie nie jest, a jednak jest. W ostatnim rozdziale w roli głównej występują czołowi przedstawiciele tej grupy społecznej z obozu narodowego - Roman Dmowski, Zygmunt Balicki oraz Jan Ludwik Popławski. Interesujące przy tym, że w całej książce ani razu nie pada nazwisko Józefa Piłsudskiego. Wydaje się, że deklarowanego upodmiotowienia plebsu nie da się zamknąć w ciasne ramy proponowanych przez Marca rozdziałów.

Sam Autor jednak zaczyna pierwszy rozdział od kwestii chłopskiej w podrozdziale „Proletaryzacja” (s. 53), zwracając uwagę na wpływ rozwoju kapitalizmu na wzrost miast i proletaryzacji chłopów. Jako ilustrację industrializacji Królestwa Polskiego podaje przykład rodzimej Łodzi, której liczba mieszkańców w latach 1850-1900 wzrosła dzięki temu aż o 2006\%. Kontynuując swoje rozważania („Nowe repertuary kontestacji”, s. 58), stwierdza, iż wystąpienia robotników do 1905 r. były przednowoczesne, ich uczestnicy nie wiedzieli, jak się zachowywać i organizować, nie znali instytucji politycznych. Podzielam opinię, że wejście w nowoczesność polityczną było drogą od lokalnych, partykularnych i podzielonych form do kosmopolitycznych, autonomicznych i modularnych. Przy tym następowała reorganizacja polityki masowej, pojawiły się nowe formy kontestacji w postaci ruchów miejskich. Tym samym została „przełamana bariera strachu”. Wraz z rozpoczęciem rewolucji styczniowy strajk (oczywiście łódzki), de facto jeden $z$ niewielu prawdziwych strajków powszechnych, zaskoczył wszystkich. Nie ma nowego głosu w tym (Autor m.in. przywołuje prace o kulturze politycznej robotników), że strajki polityczne są świadectwem powstawania szerokiej, klasowej wspólnoty wyobrażonej. Strajk solidaryzował, a udany dawał nadzieję na długoterminową działalność, obecność głosu podmiotu na forum publicznym. Forum to zaczynało się od ulicy i fabryki. Budowanie barykad na ulicach i formowanie zwartych szeregów na demonstracjach - to wyraz kolektywnego działania, a noszenie czerwonych wstążek jako łączącej oznaki nie miały miejsca wcześniej ${ }^{32}$. Jako własne formy strefy publicznej robotnicy odbierali święta, pomagały w tym ulotki partii, gdyż wcześniej proletariusze nie mieli wzorców zachowania politycznego - przykładem obchody własnego święta robotniczego 1 maja ${ }^{33}$. Z kolei masowe

31 T. Shanin, Revolution as a Moment of Truth, New Haven 1986; wyd. ros.: Т. Шанин, Революиия как момент истины. Россия 1905-1907 г2. - 1917-1922 г2., Москва 1997.

32 Po raz pierwszy pod czerwonym sztandarem w Imperium Rosyjskim solidarnie wystąpili właśnie chłopi wsi Kandijewki w guberni penzeńskiej, wyrażając swoje niezadowolenie z warunków carskiego Manifestu z 1861 r., Из рапорта свитского генерал-майора А.М. Дренякина от 13 мая 1861 г. Александру II о волнениях крестьян в Чембарском и Керенском уездах Пензенской губернии и о расправе с ними, ш: Конеи, крепостничества в России (документы, письма, мемуары, статьи), сост., общ. ред., вст. ст. и коммент. В.А. Федоров, Москва 1994, s. $277-$ 285. Oprócz noszenia czerwonego koloru rewolucjoniści ubierali się często również na czarno.

33 Первое мая в иарской России. 1890-1916 г2. Сборник документов, общ. ред. О. Чаадаева, Москва 1939. 
pogrzeby oraz demonstracje na wzór procesji religijnych ('spiewy, chorągwie) były kontynuacją zmienionych na nowoczesne praktyk.

Nie tylko ulice, ale też salony, mieszkania prywatne czy sale teatralne stały się forum publicznym. Później dołączyły fabryki, których autonomii zaciekle bronili robotnicy. W zakładach nie tylko agitowali i dyskutowali, ale też prowadzili pertraktacje z fabrykantami, nie wpuszczając policji. Do tej listy warto dorzucić tanie stołówki ${ }^{34}$ robotnicze oraz herbaciarnie, które odgrywały rolę „klubów” robotniczych $^{35}$. Właśnie głód w tym przypadku był drogą do pojawienia się proletariackiej sfery publicznej w lokalach gastronomicznych. Niestety Autor nie poświęca prawie wcale miejsca (oprócz s. 90 nn.) „giełdom” robotniczym („birżom”). „Birże”, które śmiało można nazwać jedną z podstawowych zdobyczy partycypacji miejskiej w okresie rewolucji 1905 roku, istniały prawie w każdym ogarniętym rewolucją mieście Królestwa Polskiego i Północno-Zachodniego Kraju. Były zarówno partyjne, jak też ogólnomiejskie. Przykładami ulica Suraska w Białymstoku, ulica Szosejna w Brześciu, Nabrzeże w Słonimiu, ulice: Miła, Dzika, Dzielna, Nalewki, Pawia $\mathrm{i}$ in. w Warszawie, ulice: Południowa i Wschodnia w Łodzi, Plac Paradny w Grodnie, ulica Kuźnicza w Homlu, ulice: Gubernatorska i Zachariewska w Mińsku itd. Wspomnienia uczestników wydarzeń rewolucyjnych w konfrontacji z raportami policyjnymi szkicują dość ciekawy wizerunek tych miejsc. I jedna, i druga strona barykady podkreślały znaczenie giełd robotniczych ${ }^{36}$. O niektórych z nich krążyły legendy. „Birże” dawały przestrzeń dla kontaktów robotników różnych fachów i narodowości, służyły trybunałom rewolucyjnym, pełniły funkcje sklepów, bibliotek oraz sekretariatów związków zawodowych, były forum do dyskusji i debat politycznych robotników wszystkich zawodów, narodowości i orientacji politycznych, często pracujących w porozrzucanych daleko od siebie zakładach i warsztatach. Były dla proletariatu zarówno szkołą rewolucyjną, jak też tymi wszystkimi instytucjami nowoczesnej polityki, gdzie pluralizm polityczny i różnorodność mówców partyjnych kształtowały „demokratyczną przestrzeń wyobrażeniową”. Właśnie na „birżach” odbywało się uświadamianie robotników, ale też uczenie się dyskusji i polemiki, przygotowanie do samodzielnego myślenia i własnego wyboru konkretnej opcji politycznej (wyjaśnianie, czym jest Duma, ordynacja wyborcza, oraz na czym polegają mechanizmy politycznych praktyk demokratycznych). Jest to o tyle ważne, że praktyka okupacji placów i ulic miejskich obecnie uprawiana jest

${ }^{34} \mathrm{~Np}$. Bund z taniej żydowskiej stołówki zrobił dla masowo głodującego w 1904 r. proletariatu łódzkiego klub polityczny, А.Д. Киржниц, 1905. Еврейское рабочее движение. Обзор, материалы и документы, Москва-Ленинград 1928, s. 31-33.

35 Np. w Brześciu istniało przynajmniej kilka bundowskich herbaciarni, zob. Litewskie Państwowe Archiwum Historyczne, LVIA, f. 378, op. 1905, d. 8. OP, k. 56; LVIA, f. 378, op. 1907, d. 44. OP, k. 2.

36 A. Łaniewski, „Giełdy” robotnicze w Królestwie Polskim podczas rewolucji 1905 roku, „Inny Świat” (2018), nr 1 (48), s. 49-53; А. Ланеўскі, Рабочыя „біржы” у Расійскай імперыі як прататып каниэпиьі „права на горад”, w: Grodnae et orbi. Гарадскія супольнасиі і гарадское ассяроддзе, рэд. А. Радзюк, В. Галубовіч, Мінск 2018, s. 236-248. 
przez wszystkie masowe ruchy społeczno-polityczne ${ }^{37}$. Nad tym wątkiem, moim zdaniem, Autor mógłby się pochylić, tym bardziej, że do zainteresowań „Praktyki Teoretycznej” jak najbardziej należy teoria „prawo do miasta”, którą zapoczątkował w 1968 r. francuski filozof i socjolog Henry Lefebvre, a obecnie rozwija m.in. amerykańsko-kanadyjski antropolog i geograf David Harvey ${ }^{38}$.

To wszystko, według łódzkiego badacza, prowadziło do „emancypacji intelektualnej” (s. 117). Retorykę socjalizmu rozpatruje jako pierwszy dostępny i spójny język, który umożliwiał robotnikom zrozumienie świata w kategoriach szerszych relacji strukturalnych, zależności wykraczających poza konkretność codziennego doświadczenia. Trafnie podkreśla, że aktywizacja polityczna wzmagała ciekawość świata i wspomagała dążenie do zdobywania wiedzy (rola teatru i bibliotek). Dodać można, że robotnicy żydowscy śpiewali piosenki w zakładach, co z kolei budowało niezwykłą atmosferę solidarności ${ }^{39}$. Robotnicy, tworząc własne sfery, zmieniali status quo. Druki aktywnie współtworzyły zewnętrzny świat robotników, budowały wspólnotę poprzez wprowadzenie wspólnego języka pojęciowego, stając się ważną częścią historii intelektualnej robotników, umiejscawiały odbiorców w danej sytuacji oraz w świecie. Prasa pełniła funkcję łączności partyjnej oraz na linii inteligencja-proletariat. Odbywało się krążenie egzemplarzy wśród czytelników oraz wspólne czytanie. Takie „socjalistyczne oświecenie” polegało na wytłumaczeniu świata kapitalizmu jako całości.

Innym ważnym elementem „powołania podmiotowości” proletariatu była jego samoidentyfikacja, uzyskanie godności osobistej oraz nadanie określonej samokonstrukcji. Poprzez ulotki, w których do czytelników zwracano się: „Polacy”, „bracia”, „robotnicy”, „towarzyszki” itd., czytelnik stawał się współuczestnikiem odezwy. Analizując struktury językowe, Marzec dochodzi do wniosku, że w rewolucyjnych ulotkach zwrotu „My” najczęściej używała SDKPiL. Natomiast największy dystans na linii nadawca-odbiorca cechował NZR i endecję, gdzie przeważnie korzystano $\mathrm{z}$ takich form jak: polecenie, rozkaz, przydzielenie konkretnego miejsca we wspólnocie wyobrażonej, pouczenie z pozycji władzy i hierarchii. Zdaniem Autora, nawoływanie do działania i walki należy postrzegać jako proces tworzenia się przyszłych demokratycznych form wspólistnienia w życiu publicznym proletariatu. W ów „chrzest językowy”, czyli określenie rewolucji jako kompleksu różnorodnych wydarzeń, nadawanie spójnej tożsamości zdarzeń

37 Np. Occupy movement (USA), Indigados (Hiszpania), Geração à Rasca (Portugalia), okupacje placu Tahrir (Egipt) i Placu Taksim (Turcja), Euromajdan (Ukraina). Inicjatywy „Prawo do miasta" działają także w kilku polskich miastach.

${ }^{38}$ H. Lefebvre, Le droit à la ville, Paris 1968; wyd. pol.: Prawo do miasta, „Praktyka Teoretyczna” (2012), nr 5, s. 183-197; D. Harvey, Bunt miast. Prawo do miasta i miejska rewolucja, tłum. A. Kowalczyk [i in.], Warszawa 2012. Zob. А. Ланеўскі, Рабочыя „біржы”...

39 P. Sapoznikov, The Revolutionary Movement in Kobrin 1904-1905, w: Book of Kobrin; the scroll of life and destruction, eds. B. Shwartz, I.C. Bil(e)tzki, transl. N. Avidan, A. Perry, San Francisco 1992, p. 138. 
oraz konkurencyjnej tożsamości podmiotów (s. 171), różne grupy wkładały własny sens. Narodowa Demokracja np. do opisu rewolucji najczęściej używała hasła „anarchia”.

Inną płaszczyzną kształtowania się wspólnych wartości była komemoracja (nekrologi, rocznice), udzielanie na łamach prasy głosu kobietom oraz korespondencje $\mathrm{z}$ dalekich fabryk i warsztatów. Stopniowo w prasie nastąpił rozwój polemicznej sfery publicznej: pojawiły się komentarze i krytyka obcych programów politycznych. Wartym odnotowania jest także fakt, iż na łamach prasy zaczęto drukować rubryki „Bojkot” i „Przeprosiny”, które bezspornie umacniały robotników w poczuciu własnej godności i siły.

Próbując udowodnić założenie, że rewolucja przyśpieszyła długotrwałe zrzucanie „skorupy ciemnoty”, torując drogę do świata pism i lektur, Wiktor Marzec zwraca się ku analizie biografii trzech robotników $w^{40}$. Jak pisze sam socjolog, „traf chciał" (s. 207), że wszyscy ci bohaterowie należeli wyłącznie do SDKPiL (a później KPP). To naturalnie może budzić pewnego rodzaju niedosyt. Bohaterami biograficznego wątku zostali: Stanisław Pestkowski, Franciszek Łęczycki i Lucjan Rudnicki. „Przekraczając siebie” poprzez m.in. „świadomą drogę do świata pisania", przeżywali transformację kulturową. Polegała ona na wyjściu poza biologiczną powtarzalność, jaką dla plebsu była praca fizyczna. A to wszystko odbywało się za pomocą udziału w publicznej sferze proletariackiej i zmiany samoidentyfikacji zdobytej za sprawą wiedzy politycznej, którą intensyfikowała rewolucja.

Rozdział „Rewolucja” zaczyna Marzec od zagadnień teoretycznych, skupiając się na analizie programów partii i związanych z nimi tożsamości politycznych. Uważa, że w Królestwie Polskim pole polityczne zaczął kształtować nie podział na linii lud-zaborca, a na linii lud-reżim (s. 236). Podkreślając stałą dwutorowość polskiego ruchu socjalistycznego, zwraca się ku konceptom dwu partii. Pokrótce omawia poglądy liderki SDKPiL Róży Luxemburg, zaznaczając, że nie była przeciwko narodowości pojmowanej kulturowo, występując przeciwko germanizacji. Jej dyskurs antykapitalistyczny był najbardziej abstrakcyjny i teoretyczny. PPS z kolei rzadziej zwracała się do ludu (plebsu), a częściej do ludu pracy (robotników). W dodatku PPS, krytykując opresyjne i obce instytucje państwowe, zapominała o przekonywaniu, że żołnierze $\mathrm{z}$ innych zakątków imperium również należą do represjonowanej klasy (chłopów). Natomiast użycie haseł „lud roboczy” czy "obywatele polscy" pomagało PPS-Lewicy w budowaniu szerszego frontu rewolucyjnego (włączając chłopów i drobne mieszczaństwo), socjalistycznej i narodowej wspólnoty wyobrażonej z innymi mieszkańcami kraju.

Oprócz wspomnianych już chłopów i żołnierzy, ważnym elementem w rewolucji 1905 roku byli więźniowie. Jeżeli w wypadku niezależnie od ustroju państwowego

40 Dziwnym trafem w książce zabrakło fundamentalnego dla badaczy polskiej lewicy słownika: Słownik bioraficzny działaczy polskiego ruchu robotniczego, red. nacz. F. Tych, t. 1-3, Warszawa 1978-1992. 
i okresu historycznego niezmiennie hermetycznej i hierarchicznej struktury, jaką jest wojsko - mimo buntów i aktywnego udziału żołnierzy w rewolucji 1905 roku - ciężko mówić o jakiejkolwiek wywalczonej przestrzeni publicznej, to kwestie związanie z więźniami politycznymi, a zwłaszcza wpływ represji i „szkoły więziennej" na walkę o godność w więzieniach (nie tylko na ulicach i w fabrykach), na wywalczanie podmiotowości poprzez solidarne wsparcie uwięzionych towarzyszy, nigdy nie doczekały się głębszych badań ${ }^{41}$. Inna nieobecna sfera publiczna to masowo powstające wówczas związki zawodowe. Jakie miejsce w kształtowaniu współczesnych dyskursów politycznych miały te organizacje robotnicze, w których niewątpliwie kształtowała się podmiotowość i kultura robotnicza? Te kwestie zostały pominięte przez Autora ${ }^{42}$.

Pisząc o ruchu narodowym, Autor już na wstępie podkreśla braki w bazie źródłowej tej opcji politycznej, zaznaczając m.in., że co do liczby pozostawionych relacji członków, NZR znacznie przegrywa z socjalistami (s. 253 nn.). Ponadto zwraca uwagę na wtórność narodowych formacji robotniczych, które zaczęto powoływać w odpowiedzi na socjalistyczne pojmowanie świata, które, jego zdaniem, zawładnęło już dużą częścią polskich robotników. Omawiając nacjonalizm „oddolny”, przypomina, że grunt do rozwoju NZR był stworzony już wcześniej (przed rewolucją Łódzkie Towarzystwo Oświaty Narodowej było najliczniejszą organizacją robotniczą w mieście). W pierwotnej fazie rewolucji NZR odwoływał się do poprawy bytu robotników, aprobował strajki. Jako element emancypacji od paternalizmu fabrycznego, zdaniem badacza, miała miejsce organizacja kółek fabrycznych. Marzec pisze, że w środowisku robotniczym ze względu na socjalistyczną dominację ulotki narodowe należą do jednych z najciekawszych (s. 260). Mamy w nich do czynienia z ciągła grą z kontekstem, gdyż dyskurs narodowy wykształcał się w polemicznym kontekście, i polegał na próbie przekonywania robotników mających inne poglądy oraz budowania łączności między różnymi grupami społecznymi poprzez wspólne cierpienie ${ }^{43}$.

Wybory do Dumy przyczyniły się do wzmocnienia NZR, który zresztą również uczestniczył w nauczaniu robotników posługiwania się mechanizmami parlamentarnymi. Właśnie po wygranej Narodowa Demokracja dała robotnikom poczucie, że do realnej polityki weszli razem. Mimo to, za sprawą endecji odbywała się nie tylko

${ }^{41}$ Częściowo ten wątek został podjęty np. w: И. Генкин, По тюрьмам и этапам, Петербург 1922; E. Kaczyńska, Ludzie ukarani. Więzienia i system kar w Królestwie Polskim 1815-1914, Warszawa 1989.

42 Zob. I. Orzechowski, A. Kochański, Zarys dziejów ruchu zawodowego w Królestwie Polskim (1905-1918), Warszawa 1964; Ruch zawodowy w Polsce: zarys dziejów, t. 1: 1869-1918, oprac. J. Kancewicz [i in.], red. S. Kalabiński, Warszawa 1974; R. Chwedoruk, Ruchy i myśl polityczna syndykalizmu w Polsce, Warszawa 2011; G. Zackiewicz, Syndykalizm w polskiej refleksji i rzeczywistości politycznej I połowy XX wieku, Kraków 2013.

${ }^{43}$ Warto zadać pytanie: czy dyskurs rewolucyjny nie był także tworzony w polemice między różnymi nurtami lewicowymi? 
pluralizacja, ale też antagonizacja dyskursu politycznego (s. 281). Badacz z Łodzi, analizując treść ulotek, odnotowuje w nich dominującą hierarchiczną wizję świata. Odezwy NZR cechowały się większą agresją, z kolei socjalistyczne, chociaż nieraz używały „niewybrednych sformułowan”, krytykując walki bratobójcze, nawoływały jednak do kultury dyskusji (zwłaszcza PPS). Nie jest rzeczą nową, że antysemityzm głośno przebija się przez ulotki narodowców, o czym Autor przypomina, przytaczając tekst piosenki: „Giń spodlony ty Żydzie, już cię Marks nie obroni” (s. 283). Niemniej jednak Wiktor Marzec stara się doszukać w retoryce NZR także tendencji demokratycznych, m.in. zwracając uwagę na oddolne przyjęcie rezolucji o zakończeniu walk bratobójczych przez NZR, co świadczyło o kulturze politycznej robotników. Jako element procesu „dyscyplinowania demokracji” ze strony endecji wymieniane są tworzące się bojówki i milicje narodowe. Ta dążąca do utrzymania $\mathrm{w}$ ryzach robotników zmiana dyskursu dyscypliny powodowała, że ulotki socjalistyczne coraz częściej odwoływały się do endecji, krytykując jej hierarchię i dyscyplinę. W tym miejscu należy przypomnieć, że owa hierarchia i dyscyplina były niezbędnymi cechami każdej partii politycznej, i socjaliści różnych odcieni nie stanowili tu wyjątku. Jedynymi radykalnie wyłamującymi się pod tym względem byli anarchiści, z założenia odrzucający jakąkolwiek hierarchię i partyjnośćc ${ }^{4}$.

W jednej z recenzji zwrócono uwagę na „kompletną nieobecność kobiet w narracjach rewolucjonistów i dokumentach cytowanych przez autora”. W książce przywołano tylko Różę Luksemburg i Esterę Golde ${ }^{45}$. Ciekawym wątkiem w kontekście rozważań Marca byłoby prześledzenie i porównanie genderowego aspektu socjalistycznych i narodowych ulotek. O genderowej analizie ulotek łódzki badacz jednak nie wspomina. Oczywiście nie ma obowiązku tego robić.

Autor, wyliczając pola aktywności NZR, nie uwzględnia roli Kościoła katolickiego, który zresztą go nie interesuje (s. 36). Nie analizuje powstawania chrześcijańskich związków robotniczych, m.in. nie wzmiankuje o Stowarzyszeniu Robotników Chrześcijańskich z ks. Maurycym Godlewskim na czele ${ }^{46}$. Analiza ich ulotek oraz relacji z NZR i socjalistami mogłaby rozszerzyć perspektywę dychotomii socjaliści-endecja i odpowiedzieć na pytanie: czy SRCh miał wpływ na kształtowanie się nowoczesnych dyskursów politycznych? Wydaje się, że tysiące członków i dziesiątki grup (w przyszłości mające współtworzyć Chrześcijańską Demokrację) mieli pewien wpływ na kształtowanie się nowoczesnych dyskursów politycznych. Marzec pomija także Związek Młodzieży Polskiej „ZET”, a NZR traktowany jest

${ }^{44}$ I za to byli zaciekle atakowani przez wszystkich socjalistów. Jako przykład zob. broszurę PPS: Anarchizm a bandytyzm, Warszawa 1906.

${ }^{45}$ E. Glubińska, Rebelia i reakcja. Rewolucja 1905 roku i plebejskie doświadczenie polityczne - Wiktor Marzec, http://szuflada.net/rebelia-i-reakcja-rewolucja-1905-roku-i-plebejskie-doswiadczenie-polityczne-wiktor-marzec/ (dostęp: 1.10.2018).

${ }^{46}$ Zob. R. Bender, Społeczne inicjatywy chrześcijańskie w Królestwie Polskim, Lublin 1978; W. Gliński, Stowarzyszenie Robotników Chrześcijańskich w łódzkim okręgu przemysłowym (1905-1914), „Łódzkie Studia Teologiczne” (2015), nr 2, s. 61-70. 
jako filia Narodowej Demokracji, wykorzystywana przez endecję ${ }^{47}$. Z tego wynika poniekąd jednolite traktowanie obozu narodowego, który - o czym Autor wie (s. 299 nn.) - ówcześnie tworzył nie do końca jednolitą mozaikę ${ }^{48}$.

W podsumowaniu rozdziału Wiktor Marzec wyodrębnia 4 fazy przekształcenia pola politycznego w Królestwie Polskim: 1) binarna polaryzacja pola - opór przeciw caratowi; 2) krystalizacja - artykułowanie konkretnej tożsamości politycznej (za pomocą metafory); 3) polaryzacja antagonistyczna - zwalczanie przeciwników (ironia, sarkazm); 4) wygrana endecji - opanowanie sfery robotniczej (s. 292-294). Wywody Marca nie są wiarygodne bez precyzyjnego zestawienia omówionych źródeł. Zabrakło przy tym podania konkretnej ilości, nazw i dat ulotek. Z ogólnej liczby ponad 800 ulotek, o których wspomina Autor (s. 460), cytuje około 100. Moim zdaniem, taka proporcja jest daleka od satysfakcjonującej.

Bodajże najciekawszy rozdział jest poświęcony reakcji, która była odpowiedzią polskiego nacjonalizmu na wyzwania nowoczesności i demokratyzacji. Marzec analizuje zachodzące w latach 1880-1905 zmiany w definiowaniu takich pojęć jak „naród”, „lud”, „demokracja”. Właśnie „lud” staje się ważnym pojęciem w dyskusjach i ideach rodzącego się obozu narodowego. Jan Ludwik Popławski włącza do tej kategorii chłopów. Staje się to dzięki ogólnie sprzyjającym warunkom epoki (rozwój antropologii, folklorystyki itd.). Niemniej, mimo pierwotnych wątków demokratyzacji i emancypacji „ludu”, w okresie rewolucji jego wizja plebsu stopniowo zawężała się, żeby w końcu sprowadzić się wyłącznie do roli wykonawcy dążeń politycznych. Innymi słowy, zarządzanie tym ludem powinno było znaleźć się w rękach osób mających ku temu predyspozycje - endecji.

Pierwotnie endecja opowiadała się za gminowładztwem oraz rozproszoną demokracją bezpośrednią, widziała niebezpieczeństwo w oligarchizacji (Z. Balicki), z czasem jednak sama padła jej ofiarą. Ujawniło się to w dążeniu do powstrzymania demokratyzacji poprzez nadzór elit oraz zredukowanie mas ludowych jedynie do narzędzia polityki masowej. W tej ewolucji pojęć „lud” i „demokracja” jako odpowiedzi na zetknięcie się myśli endeckiej z plebsem Marzec doszukuje się korzeni totalitaryzmu. W momencie pojawienia się wielości głosów upominających się o własne prawa endecja zastąpiła demokratyzację zdyscyplinowaniem, scalając grupy poprzez odniesienie do negatywnego zewnętrza. Dlatego

47 P. Waingertner, Zet wobec Narodowej Demokracji w przededniu I wojny światowej, „Acta Universitatis Lodziensis. Folia Historica" (1998), nr 63, s. 161-173.

48 Niektóre nieuwzględnione przez Autora pozycje: W. Pobóg-Malinowski, Narodowa Demokracja, 1887-1918, Warszawa 1933; M. Orzechowski, Narodowa Demokracja na Górnym Śląsku (do 1918 roku), Wrocław 1965; J. Marczewski, Narodowa Demokracja w Poznańskiem: 1900-1914, Warszawa 1967; Narodowa Demokracja: antologia myśli politycznej „Przeglądu Wszechpolskiego” (1895-1905), wybór, wstęp i oprac. B. Toruńczyk, Londyn 1983; A. Wątor, Narodowa Demokracja w Galicji do 1918 roku, Szczecin 2002; Narodowa Demokracja XIX-XXI wiek: (koncepcje - ludzie - działalność), red. T. Sikorski, A. Wątor, Szczecin 2008; O. Bergman, Narodowa Demokracja a Żydzi 1918-1929, Poznań 2015. 
ewoluująca w kierunku integralnego nacjonalizmu oraz autorytarnej dyscypliny myśl Narodowej Demokracji była formą nowoczesnej filozofii politycznej.

Najlepszym odzwierciedleniem tej filozofii stały się Myśli nowoczesnych Polaków (s. 341). Wszystkie dyskursy polityczne tego okresu, zdaniem badacza, ciągle podważały zasady istniejącego ładu społecznego. Endecja, jako ruch nowoczesny, również stawiała czoło zmianom. $\mathrm{Z}$ innej strony w zakresie samoświadomości próbowała tworzyć $\mathrm{z}$ adeptów swoich idei aktywnych twórców zachodzących zmian. Dyskurs endecki polegał wówczas na „zmaganiu się z kryzysem uzasadnienia”, czyli próbą odnalezienia formuły dla niewymagającego dodatkowych uzasadnień absolutu narodowego. Trajektoria zmagania się z demokratyzacją przebiegała z kolei od upodmiotowienia ludu, poprzez przejęcie kierownictwa nad nim, aż po „elitarystyczny i autorytarny obskurantyzm" (s. 345).

Opisując "narodowy absolut w czasach kryzysu”, autor udowadnia, że $\mathrm{w}$ momencie wyczerpania się propozycji pozytywistycznych nastąpiło zredukowanie objaśniających zmieniający się świat systemów naukowych (Lefortowski „zanik markerów pewności”). Dochodził do tego brak ścieżek awansu dla dorastającej pod koniec XIX w. radykalnej inteligencji, która miała szansę na samorealizację, przyłączając się do ruchów politycznych. Dlatego naród, jako podmiot polityczny, konstruowany był w procesie walki (antagonizmu). W owej walce endecja zmagała się także „z tym, co polityczne”. Najpierw u Dmowskiego uzasadnieniem ładu narodowego była „etyka” czy też „etos indywidualny”, z czasem naród stał się bytem absolutnym i nadrzędnym, kierowanym proponowaną przez Balickiego „etyką zbiorową" (s. 360-361). Polityczne uświadomienie obywateli miało należeć do endecji, która realizowała prawdziwą rodzimą kulturę polityczną.

Związane z kryzysem tożsamości poszukiwania ugruntowania dla myśli endeckiej zaprowadziły do punktu odniesienia, jakim stała się biologiczna substancja narodu. Endecki projekt nacjonalizmu sprowadził się do formuły łączącej narodowy romantyzm i polską wersję liberalizmu, czyli pozytywizm („zmuszający do zdefiniowania narodu tu i teraz, wraz z tym, kto jest Polakiem i gdzie jest Polska", s. 372). Endecja, łącząc to w nowatorski sposób, szukała odpowiedzi i wyjścia z aktualnej kondycji egzystencjalno-filozoficznej. W wyniku tego obiektywnie opisany naród w założeniach endecji legitymizował się dzięki „biologicznej wizji integralnego narodu-rasy" (s. 373). Stopniowo zaczęła się ideowa konfrontacja Narodowej Demokracji z polityzacją mas. Według obozu narodowego socjaliści, mimo wyczucia nastroju mas, nie byli w stanie nimi pokierować, gdyż przemawiali wciąż tym samym językiem, nie tworząc nowych myślowych koncepcji rozwojowych. Do tego trzeba dodać czynnik „obcego” (zajmujący przestrzeń publiczną Żydzi oraz socjaliści ze swoimi nienarodowymi roszczeniami) i wynikający z niego lęk przed czerwonym motłochem, niecywilizowanym i niezdyscyplinowanym oraz burzącymi, a nie tworzącymi narodowe podstawy Żydami. Ową "trwogę mas" i rewolucyjny żywioł należało okiełznać. W celu trzymania „ludu pod kontrolą" Narodowa Demokracja coraz częściej używała określenia „anarchia”, którym to 
można było nazwać działania każdego przeciwnika politycznego: caratu, socjalistów, Żydów ${ }^{49}$. Rewolucja, ujawniając potencjał ludu do budowania czy przekształcenia pól politycznych, budziła niepokój endecji, wymuszając na niej „opanowanie emocji i demokratycznego nadmiaru" (s. 406) i natychmiastowe zdyscyplinowanie wspólnoty narodowej, co prowadziło do pogłębiania tendencji autorytarnych.

Narodowa Demokracja w obliczu tych działań przekształciła się w typowo nowoczesnych konserwatystów, pisze Marzec. Na jej cechy charakterystyczne złożyły się: elitaryzm (obrona warstwy inteligenckiej, jako nośnika kultury i kierownictwa państwem) oraz wyrażające się w obronie fabrykantów, czyli tego, co polskie i miejscowe, dążenie do zachowania porządku własnościowego. Jako ilustracja do tych zachowań podana jest sprawa dyrektora technicznego fabryki Biedermanna z Łodzi, Leona Koźmińskiego (s. 414-415). Idąc dalej w swoich śmiałych wywodach, Wiktor Marzec podaje kolejną cechę ówczesnej endecji. Jego zdaniem, była to składająca się z elitarności w połączeniu z mniemaną masowością „mafijność”, która m.in. przyciągała do endecji ziemiaństwo. Właśnie po 1905 r. nastąpiła zmiana bazy społecznej dzięki atrakcyjności programu i postulatów obrony ziemiaństwa przed wystąpieniami chłopów i robotników. W tym wszystkim pojawił się i na długie lata zakorzenił polityczny antysemityzm i pogarda elit wobec „ciemnych mas" 50 .

Łódzki badacz skupia się głównie na PPS i SDKPiL oraz NZR. Mnie, jako historyka anarchizmu, zraził brak analizy nurtu, który akurat w okresie rewolucji 1905 roku był niezwykle aktywny i zauważalny na scenie rewolucyjnej ${ }^{51}$. Łódzki socjolog wspomina o anarchistach zaledwie na marginesie, wzmiankując m.in. o zbliżonej do formacji anarchistycznych Grupie Rewolucjonistów Mścicieli (s. 422) ${ }^{52}$. Pozwolę sobie zaryzykować twierdzenie, że właśnie anarchiści byli zawsze o krok dalej nie tylko $\mathrm{w}$ radykalizmie, ale też $\mathrm{w}$ szerzeniu demokracji w jej najlepszym wydaniu

49 Należałoby prześledzić ten ciekawy wątek używania przez różne siły polityczne (również liberałów i socjalistów) słowa „anarchia”, starając się dać odpowiedź na pytanie: czy nie za sprawą endecji to określenie przeniknęło do współczesnych dyskursów i frazeologii politycznej? Na temat użycia słów „anarchia” i „anarchizm” zob. A. Łaniewski, Wizerunek anarchistów $i$ anarchii na łamach „Naprzodu” i „Robotnika” (1892-1927), „Dzieje Najnowsze” (2014), nr 4, s. 3-29.

${ }^{50}$ Nie negując ustaleń Autora, wydaje się jednak, że to, co usiłował pokazać Marzec w ostatniej części recenzowanej pracy, w sposób bardziej szczegółowy opracował i zaprezentował w swojej erudycyjnej monografii warszawski historyk: G. Krzywiec, Polska bez Żydów. Studia z dziejów idei, wyobrażeń i praktyk antysemickich na ziemiach polskich początku XX wieku (1905-1914), Warszawa 2017.

${ }^{51}$ Anarchizm i anarchiści na ziemiach polskich do 1914 r., zebr. i oprac. H. Rappaport, Warszawa 1981; Анархисты. Документы и материалы, т. 1: 1883-1916, ред. О.В. Волобуев, сост. авт. пред., введ. и комм. В.В. Кривенький, Москва 1998.

52 Szkoda, że Marzec powołuje się na popularyzatorską i dość słabą pracę historyka-amatora A. Sekury, Rewolucyjni Mściciele. Śmierć z browningiem w ręku, Poznań 2010. Bardziej wartościowe są: E. Ajnenkiel, Rewolucjoniści Mściciele, „Rocznik Łódzki” 29 (1980), s. 137-184; S.M. Krakowski, Motywy i cele działania Grupy Rewolucjonistów-Mścicieli (1910-1913), „Piotrkowskie Zeszyty Historyczne” (1998), nr 1, s. 45-57. 
- demokracji bezpośredniej. To właśnie anarchiści przestrzegali przed różnymi zwyrodniałymi formami państw socjalistycznych, jak też dalekimi od demokratycznych posunięciami częściowo związanych z socjalistami władz polskich (zamieszki w Krakowie w 1923 r. czy przewrót majowy). I jeszcze jedno, ulotki anarchistów, np. Łódzkiej Grupy Anarchistów-Komunistów „Internacjonał”, nieraz zaczynały się od słów: „Bracia robotnicy!”, łącząc pierwiastki „narodowy” i „robotniczy”. Ale tak to już jest, że zarówno historiografia „narodowa”, jak i współczesny dyskurs socjaldemokratyczny często udają, że anarchiści nie posiadali konstruktywnego programu. Stąd nasuwa się zasadne pytanie, które postawił jeden z recenzentów książki: „Czy zarzuty stawiane przez Marca polskiej prawicy należałoby raczej rzutować na całość aktywnej politycznie polskiej inteligencji”"53?

Jak już wspomniałem, w tekście zabrakło ponadto jednej z kluczowych partii na ówczesnej scenie politycznej - Bundu ${ }^{54}$, jak również socjalistów-syjonistów. Trzeba odnotować, że dzieje Bundu $\mathrm{z}$ tego okresu nie doczekały się gruntownego opracowania i wymagają dzisiaj obszerniejszych badań. Wiąże się to m.in. z brakiem znajomości wśród badaczy języka jidysz, który w ówczesnym ruchu rewolucyjnym, jak też w sferze publicznej w Królestwie Polskim oraz Północno-Zachodnim Kraju występował jako równorzędny wobec polskiego i rosyjskiego ${ }^{55}$. W Rebelii i reakcji proletariat żydowski gubi się między polskimi socjalistami a endecją. W tym miejscu można przypomnieć, że nie tylko endecja i anarchiści używali w swoich odezwach słowo „bracia”. Członkowie i członkinie Bundu określali się jako brider un szwester (bracia i siostry), co powinno było odzwierciedlać jeszcze bliższe więzi niż pomiędzy „towarzyszami” ${ }^{\text {. }}$. Ponadto nie doszukałem się w książce wzmianek na temat reakcji środowisk żydowskich i ich polemiki z antyżydowską retoryką endecji ${ }^{57}$. Żydzi w narracji Autora występują jako tło w rozwoju koncepcji narodowych. Rewolucja naturalnie przyśpieszyła narastanie tendencji antysemickich, ale niechętnie o Żydach endecja pisała już w programie z 1903 r. ${ }^{58}$ Koniec końców

${ }^{53}$ M. Przeperski, Wiktor Marzec - „Rebelia i reakcja. Rewolucja 1905 roku i plebejskie doświadczenie polityczne" - recenzja, https://histmag.org/Wiktor-Marzec-Rebelia-i-reakcja.-Rewolucja-1905-roku-i-plebejskie-doswiadczenie-polityczne-recenzja-15537 (dostęp: 1.10.2018).

${ }^{54}$ Zob. np. Historia Ogólno-Żydowskiego Związku Robotniczego Bund (msps), t. 1-3, red. G. Aronson, Z. Dubnow-Erlich, I.S. Herc [i in.], tłum. M. Grinberg, M. Krychow, Warszawa 1974; Бунд: Документы и материаль. 1894-1921 г2., сост. и авт. коммент. Ю. Амиантов [и др.], Москва 2010.

55 Tu m.in. pomocna by była praca, z przyczyn naturalnych niewykorzystana przez Autora, warszawskiej badaczki: J. Nalewajko-Kulikov, Mówić we własnym imieniu. Prasa jidyszowa a tworzenie żydowskiej tożsamości narodowej (do 1918 roku), Warszawa 2016.

${ }^{56}$ Najlepszym tego wyrazem jest zaczynający się właśnie od tych słów hymn partii Di Szwue (przysięga).

57 M. Kamińska, Wzmianki o koegzystencji Polaków i Żydów w tekstach opowiadań robotników łódzkich (analiza językowa), w: Dzieje Żydów w Łodzi 1820-1944, red. W. Puś, S. Liszewski, Łódź 1991, s. 165-179.

58 M. Łagoda, Dmowski, naród i państwo: doktryna polityczna „Przeglądu Wszechpolskiego” (18951905), Poznań 2002, s. 41. 
przy mówieniu o Żydach mamy do czynienia z niesprawiedliwą sytuacją absens carens. Zawężanie analizowanych przez Wiktora Marca niezwykle istotnych zagadnień do „polskiej strefy publicznej”, „polskiej tradycji intelektualnej”, polskich partii politycznych oraz ulotek pisanych po polsku naraża analizę na upodobnienie się do tak krytykowanej na początku książki historii „narodowej”.

Chwali się za to Autorowi wykorzystanie dużej liczby pozycji metodologicznych (anglosaskich). Pod tym względem warsztat Wiktora Marca jako socjologa jest na wysokim poziomie. Gorzej jest z warsztatem historyka. Poszukiwanie nowych tropów badawczych, prezentowanie nowego spojrzenia na stare kwestie są ważne i niezbędne. Tylko czy kosztem nagromadzenia metodologii, nie wypierają czasem właściwej treści? Autor skupia uwagę na analizie lingwistycznej (m.in. badania leksykometryczne), ale w bibliografii zabrakło odwołań do metodologii językoznawczej ${ }^{59}$. Łódzki socjolog oświadcza, że: „W dużym stopniu opiera się na żmudnym wydłubywaniu znaczeń i doświadczeń z rezerwuaru archiwum"60. Pytanie dotyczy tego, czy owe znaczenia nie zostały od razu zaprogramowane? Ponadto koncentruje się na odezwach centralnych komitetów partii. Warto by było sięgnąć do druków komitetów lokalnych i prześledzić ich dynamikę, ten zabieg mógłby poszerzyć perspektywę „warszawo-” i „łódzkocentryczności”. Dla przykładu praktyka polityczna PPS w Grodnie (które socjaliści - i nie tylko - uważali za polskie miasto) i PPS w Warszawie będą wykazywać sporo różnic. Grodzieńska organizacja nie musiała konkurować z NZR, wspierając przy tym białoruskich socjalistów, a jej OB w porównaniu do większości bojówek w Królestwie Polskim działała dość „pokojowo”. Od specyfiki danej miejscowości zależał również język, którym poprzez różnorodne druki „przemawiała” rewolucja. Mówiąc o OB warto zastanowić się nad pytaniem: czy stosując terror rewolucyjny, socjaliści wszelkich odcieni nie upodabniali się do nawołujących do walk „bratobójczych” endeków? Czy i w jakim stopniu terror, do którego uciekała się część robotników, wpływał na budowanie nowych sfer proletariackich ${ }^{61}$ ?

Last but not least - kwestia, w jaki sposób monografia została zredagowana. Solidne wydawnictwa $\mathrm{w}$ tym przypadku nie zadbały o doszlifowanie strony edytorskiej książki. Od razu rzuca się w oczy nietypowa, wręcz dziwna (możliwe, że tylko dla historyka) struktura pracy, gdyż omówienie bazy źródłowej znajduje się dopiero po „Zakończeniu” (s. 459). Autor nie podaje w przypisach numerów stron do artykułów, zapomina o tym, cytując m.in. Marksa (s. 21), przy tym Wiktor

59 Np. A. Pawlikowska, Zastosowanie metod językoznawstwa korpusowego i lingwistyki kwantytatywnej w analizie dyskursu, „Oblicza Komunikacji” (2012), nr 5, s. 111-125; zob. też J. Burski, K. Brzeziński, Próba wykorzystania programu komputerowego QDA Miner do realizacji projektu badawczego „Cztery dyskursy o nowoczesności - modernizm peryferii na przykładzie Łodzi (XIXXX wiek)”, „Przegląd Socjologii Jakościowej” (2014), nr 2, s. 82-99.

${ }^{60}$ Polityczność plebsu..., s. 83.

${ }^{61}$ W bibliografii zabrakło ważnej pod tym względem pracy: J. Pająk, Organizacje bojowe partii politycznych w Królestwie Polskim 1904-1911, Warszawa 1984. 
Marzec w swojej pracy przytacza sporą ilość cytatów. Są to przeważnie całe akapity. Ponadto w monografii napotkałem trochę literówek (np. s. 31, 173, 268, 347, 369, 371, 468). Częstokroć Autor powtarza się, np.: identyczne przyp. 43 na s. 61 oraz 68 na s. 71; ten sam cytat z M. Ostrowskiego w przyp. 328 na s. 181 i tekście właściwym na s. 207; wyjaśnienie użycia neutralnego słowa „endecja” (s. 299 oraz 304); „walka - szerzej antagonizm” w obydwu akapitach (s. 360). Na s. 360 i 386 przypisy powtarzają ten sam tytuł, co powoduje natłok tych samych nazwisk, tytułów itd. Błędy znalazły się również w indeksie nazwisk, np. nazwisko Pawła Samusia figuruje na s. $71,80,84,96,98$, nie doszukałem się natomiast podania tych stron w indeksie, gdzie przy nazwisku tego badacza widnieje jedynie s. 201 na tej stronie jednak w ogóle nazwiska P. Samusia nie ma. Bibliografia nie została podzielona na źródła i opracowania, na polsko- i anglojęzyczną literaturę, zabrakło w niej też tytułów prasowych. Ponadto Autor podaje przy pracach zbiorowych oddzielnie zarówno tekst konkretnego autora, jak też później tytuł książki: np. jest T. Burek, Lekcja rewolucji. O znaczeniu rewolucji 1905 roku w procesie historycznoliterackim, w: Literatura polska wobec rewolucji, red. M. Janion, Warszawa 1971 (s. 471) i jest po prostu Literatura polska wobec rewolucji (s. 483). Z innych drobiazgów można wymienić brak dat dostępu do stron internetowych.

Reasumując, należy stwierdzić, że praca Wiktora Marca jest interesującym głosem na temat polskiej nowoczesności. Interpretacja wydarzeń rewolucyjnych zaprezentowana $\mathrm{w}$ dwóch pierwszych rozdziałach, moim zdaniem, nie wnosiłaby do rodzimej historiografii radykalnie nowych ustaleń i interpretacji. Tylko w połączeniu z rozdziałem "Reakcja” stanowi ciekawą teoretyczną propozycję spojrzenia na polską nowoczesność i rewolucję 1905 roku. Jestem absolutnie pewny tego, że w przyszłości spod pióra Wiktora Marca wyjdą kolejne prace poświęcone ruchowi robotniczemu, rewolucjom i zmaganiom się z nowoczesnością. Najprawdopodobniej będą miały charakter jeszcze bardziej teoretyczny, będą jeszcze bardziej rozbudowane metodologicznie, ale taka już jest prerogatywa socjologii historycznej, w której lódzki badacz porusza się niewątpliwie sprawnie. Problematyka rewolucji 1905 roku jednak będzie nadal czekała na nowe głosy i ustalenia, w tym faktograficzne, które z całą pewnością mogą spowodować zastosowanie coraz nowych podejść metodologicznych oraz interpretacji teoretycznych.

\section{Is methodology supposed to outshine factography? A new perspective on the 1905 Revolution}

\section{Abstract}

The review article is a polemics with theses presented in the book by Wiktor Marzec Rebelia i reakcja. Rewolucja 1905 roku i plebejskie doświadczenie polityczne ["Rebellion and Reaction. The 1905 Revolution and Plebeian Political Experience”], published in Łódź and Kraków in 2016. Undoubtedly, the book which is a new and interesting voice in the discussion of problems 
of revolutionary events at the beginning of the $20^{\text {th }}$ century, according to the reviewer, is imbued with Anglo-Saxon methodology, and does not add any new factual contribution to the literature on the subject. Aleksander Łaniewski confronts a book written from the position of discourse-oriented historical sociology from the position of a historian's workshop. Focusing on random fragments of the 1905 Revolution and ignoring certain socio-political forces is not enough to discuss the plebeian political experience and to give a comprehensive description of Polish political modernity. The analysis, among others, lacked a broader discussion of political subjects from both the "regime" (e.g. Russian monarchist forces) and revolutionary (e.g. anarchist) camps, or the Christian workers' unions which were on the borderline between two poles of the revolution. Besides, in the analysis of plebeian political experience there was no voice of an extremely important ethnic factor - Jews (Bund, Zionists, Yiddish-language leaflets). In addition, some social groups (peasants, intelligentsia) and women were ignored, as well as some regions important for the 1905 Revolution (e.g. the Białystok Industrial District). It also seems that Wiktor Marzec sometimes falls into an idealization of the proletariat and Polish socialist parties. According to Łaniewski, the fragmentary treatment of the factual material, sources and literature on the subject allow to talk about the need for further research into the Revolution of 1905 . The review also underlines that the book is written in a very difficult language.

\section{Должна ли методология затмевать фактографию? Новый взгляд на Революцию 1905 года}

\section{Аннотация}

Рецензионная статья полемизирует с тезисами, которых в своей работе Rebelia i reakcja. Rewolucja 1905 roku i plebejskie doświadczenie polityczne [«Мятеж и реакция. Революция 1905 года и плебейский политический опыт»] представил Виктор Мажец. Книга, являющаяся, несомненно, новым и интересным голосом в дискуссии о проблематике революционных происшествий начала XX в., по мнению рецензента, насыщена англосаксонской методологией, не привносит новых фактографических заключений в предметную литературу. Александр Ланевский полемизирует с позиции лаборатории историка с книгой, написанной с позиции исторической социологии, ориентированной на дискурс. Обращая внимание на факт, что фокусирование на случайных фрагментах Революции 1905 года а также игнорирование некоторых общественно-политических сил, не достаточны для рассмотрения плебейского политического опыта и целостного описания польской политической современности. М. пр. в анализе не хватает более широкого обсуждения политических субъектов как с «режимного» (нпр. российские монархические силы), как и революционного (нпр. анархисты) лагерей или христианских союзов рабочих, находящихся на границе двух полюсов революции. Кроме того, в анализе плебейского политического опыта не хватает голоса неизменно важного этнического фактора - евреев (Бунд, сионисты, листовки на идиш). Вдобавок, были проигнорированы некоторые социальные слои (крестьяне, интеллигенция) и женщины, а также некоторые существенные для периода Революции 1905 года регионы (нпр. Белостокский промышленный округ). Также, кажется, что Виктор Мажец иногда впадает в идеализацию пролетариата и польских социалистических партий. Согласно мнению Ланевского, фрагментарная трактовка фактографии, источников и предметной литературы позволяют говорить о необходимости дальнейших исследований Революции 1905 года. Кроме того, в рецензии было подчеркнуто, что книга написана сложным для восприятия языком. 


\section{Bibliografia}

\section{Źródła archiwalne:}

Litewskie Państwowe Archiwum Historyczne w Wilnie (Lietuvos valstybės istorijos archyvas, LVIA), f. 378, op. 1905, d. 8. (OP); f. 378, op. 1907, d. 44. (OP).

Нацыянальны гістарычны архіў Беларусі ў г. Гродна (НГАБ у Гродне), ф. 366, оп. 1, д. 95.

\section{Opracowania i artykuły:}

„Mówią Wieki” (2015), nr 1.

„Praktyka Teoretyczna”, http://www.praktykateoretyczna.pl/.

Rewolucja1905.pl.

Anarchizm a bandytyzm, Warszawa 1906.

Anarchizm i anarchiści na ziemiach polskich do 1914 r., zebr. i oprac. H. Rappaport, Warszawa 1981.

Ajnenkiel E., Rewolucjoniści Mściciele, „Rocznik Łódzki” 29 (1980), s. 137-184.

Baumgarten L., Dzieje Wielkiego Proletariatu, Warszawa 1966.

Bender R., Społeczne inicjatywy chrześcijańskie w Królestwie Polskim, Lublin 1978.

Bendyk E., Oburzeni 1905. Zapomniana rewolucja z początku XX w., https://www.polityka.pl/ tygodnikpolityka/historia/1622495,2,zapomniana-rewolucja-z-poczatku-xx-w.read.

Bergman O., Narodowa Demokracja a Żydzi 1918-1929, Poznań 2015.

Boerner I., Pamiętnik $z$ lat 1904-1905 (wraz z załacznikami), red. T. Karbowniczek, Piotrków Trybunalski 2011.

Bogalecki T., Łódzkie barykady wolności i godności: czerwiec 1905 roku, Łódź 2010.

Bogucka M., Gorsza płeć. Kobieta w dziejach Europy od antyku po wiek XXI, Warszawa 2005.

Burski J., Brzeziński K., Próba wykorzystania programu komputerowego QDA Miner do realizacji projektu badawczego „Cztery dyskursy o nowoczesności - modernizm peryferii na przykładzie Łodzi (XIX-XX wiek)”, „Przegląd Socjologii Jakościowej” (2014), nr 2, s. 82-99.

Chwedoruk R., Ruchy i myśl polityczna syndykalizmu w Polsce, Warszawa 2011.

Ciechomska M., Od matriarchatu do feminizmu, Poznań 1996.

Cymbrowski B., Frysztacki K., Socjologowie patrza wstecz. Socjologia historyczna między teoria społeczną a splotem subdyscyplin szczegółowych, w: Socjologia historyczna. Wokół wyzwań i praktyki badawczej, red. iidem, Opole 2015, s. 11-20.

Cymbrowski B., Od historyzmu do socjologii historycznej. Szkic o metodologii, w: Socjologia historyczna. Wokół wyzwań i praktyki badawczej, red. idem, K. Frysztacki, Opole 2015, s. $61-78$.

Dobrowolski P., Narodowa Demokracja byłego Wielkiego Księstwa Litewskiego: studium z zakresu myśli politycznej i działalności obozu narodowego na ziemiach litewsko-białoruskich $w$ latach 1897-1918, Kraków 2010.

Domańska E., Historia egzystencjalna. Krytyczne studium narratywizmu i humanistyki zaangażowanej, Warszawa 2012.

Domańska E., Historie niekonwencjonalne. Refleksja o przeszłości w nowej humanistyce, Poznań 2006.

Dzido M., Kobiety Solidarności, Warszawa 2016.

Dziedzictwo rewolucji 1905-1907, red. A. Żarnowska [i in.], Warszawa-Radom 2007.

Giter-Granatsztajn N., Barykady i katorga. Wspomnienia anarchisty, Poznań 2015.

Gliński W., Stowarzyszenie Robotników Chrześcijańskich w łódzkim okręgu przemysłowym (1905-1914), „Łódzkie Studia Teologiczne” (2015), nr 2, s. 61-70. 
Glubińska E., Rebelia i reakcja. Rewolucja 1905 roku i plebejskie doświadczenie polityczne Wiktor Marzec, http://szuflada.net/rebelia-i-reakcja-rewolucja-1905-roku-i-plebejskie-doswiadczenie-polityczne-wiktor-marzec/.

Harvey D., Bunt miast. Prawo do miasta i miejska rewolucja, tłum. A. Kowalczyk [i in.], Warszawa 2012.

Historia Ogólno-Żydowskiego Związku Robotniczego Bund (msps), t. 1-3, red. G. Aronson, Z. Dubnow-Erlich, I.S. Herc [i in.], tłum. M. Grinberg, M. Krychow, Warszawa 1974.

Jarska N., Kobiety z marmuru. Robotnice w Polsce w latach 1945-1960, Warszawa 2015.

Kaczyńska E., Ludzie ukarani. Więzienia i system kar w Królestwie Polskim 1815-1914, Warszawa 1989.

Kamińska M., Wzmianki o koegzystencji Polaków i Żydów w tekstach opowiadań robotników łódzkich (analiza językowa), w: Dzieje Żydów w Łodzi 1820-1944, red. W. Puś, S. Liszewski, Łódź 1991, s. 165-179.

Kancewicz J., „Społeczeństwo i polityka - dorastanie do demokracji. Kultura polityczna w Królestwie Polskim na początku XX wieku”, red. Anna Żarnowska, Tadeusz Wolsza, Warszawa 1993 [recenzja], „Przegląd Historyczny” 85 (1994), nr 4, s. 500-507.

Kizwalter T., Zapomniana rewolucja i jej kłopotliwe skutki. O książce „Rebelia i reakcja” Wiktora Marca, http://kulturaliberalna.pl/2017/04/04/marzec-rebelia-reakcja-recenzja-kizwalter/.

Koberdowa I., Socjalno-Rewolucyjna Partia Proletariat, Warszawa 1981.

Kowalczyński K.R., Łódź 1905. Kulisy rewolucji, Łódź 2017.

Kółka socjalistyczne, gminy i Wielki Proletariat. Procesy polityczne 1878-1888. Źródła, oprac. i wstęp L. Baumgarten, Warszawa 1966.

Krakowski S.M., Motywy i cele działania Grupy Rewolucjonistów-Mścicieli (1910-1913), „Piotrkowskie Zeszyty Historyczne" (1998), nr 1, s. 45-57.

Kubicki P., Wynajdywanie miejskości, Kraków 2016.

Kula M., Historycy a socjologowie dziś, w: Socjologia historyczna. Wokół wyzwań i praktyki badawczej, red. B. Cymbrowski, K. Frysztacki, Opole 2015.

Leder A., Prześniona rewolucja. Ćwiczenia z logiki historycznej, Warszawa 2014.

Lefebvre H., Le droit à la ville, Paris 1968.

Lefebvre H., Prawo do miasta, „Praktyka Teoretyczna” (2012), nr 5, s. 183-197.

Luksemburg R., O rewolucji: Rosja 1905, 1917, red. P. Wielgosz, Warszawa 2008.

Łagoda M., Dmowski, naród i państwo: doktryna polityczna „Przeglądu Wszechpolskiego” (18951905), Poznań 2002.

Łaniewski A., „Giełdy” robotnicze w Królestwie Polskim podczas rewolucji 1905 roku, „Inny Świat" (2018), nr 1 (48), s. 49-53.

Łaniewski A., Wizerunek anarchistów i anarchii na łamach "Naprzodu” i „Robotnika” (18921927), „Dzieje Najnowsze” (2014), nr 4, s. 3-29.

Machajski J.W., Pracownik umysłowy i inne pisma, wprow. i red. nauk. P. Laskowski, Warszawa 2016.

Marczewski J., Narodowa Demokracja w Poznańskiem: 1900-1914, Warszawa 1967.

Micińska M., Wiktor Marzec, Rebelia i reakcja. Rewolucja 1905 roku i plebejskie doświadczenie polityczne [recenzja], „Kwartalnik Historyczny” 125 (2018), nr 3, s. 779-782.

Mrozik A., Akuszerki transformacji. Kobiety, literatura i władza w Polsce po 1989 roku, Warszawa 2012.

Narodowa Demokracja XIX-XXI wiek: (koncepcje - ludzie - działalność), red. T. Sikorski, A. Wątor, Szczecin 2008.

Narodowa Demokracja: antologia myśli politycznej „Przeglądu Wszechpolskiego” (1895-1905), wybór, wstęp i oprac. B. Toruńczyk, Londyn 1983.

Orzechowski I., Kochański A., Zarys dziejów ruchu zawodowego w Królestwie Polskim (19051918), Warszawa 1964. 
Orzechowski M., Narodowa Demokracja na Górnym Śląku (do 1918 roku), Wrocław 1965.

Ozimek M., Wyobraźnia teoriopolityczna. Kilka uwag na marginesie książki Rebelia i reakcja. Rewolucja 1905 roku i plebejskie doświadczenie polityczne Wiktora Marca, „Society Register" (2017), nr 1, s. 167-181.

Pająk J., Organizacje bojowe partii politycznych w Królestwie Polskim 1904-1911, Warszawa 1984.

Pawlikowska A., Zastosowanie metod językoznawstwa korpusowego i lingwistyki kwantytatywnej $w$ analizie dyskursu, „Oblicza Komunikacji” (2012), nr 5, s. 111-125.

Pobóg-Malinowski W., Narodowa Demokracja, 1887-1918, Warszawa 1933.

Polityczność plebsu. Z Wiktorem Marcem, autorem książki Rebelia i reakcja. Rewolucja 1905 roku i plebejskie doświadczenie polityczne, rozmawia Magda Roszkowska, „Notes na 6 Tygodni” (2016/2017), nr 109, s. 81-89.

Potkański W., Odrodzenie czynu niepodległościowego przez PPS w okresie rewolucji 1905 roku, Warszawa 2008.

Przeperski M., Wiktor Marzec - „Rebelia i reakcja. Rewolucja 1905 roku i plebejskie doświadczenie polityczne" - recenzja, https://histmag.org/Wiktor-Marzec-Rebelia-i-reakcja.-Rewolucja-1905-roku-i-plebejskie-doswiadczenie-polityczne-recenzja-15537.

Raleen, Rewolucja 1905 (Krytyka Polityczna \& Departament Gier), http://portal.strategie. net.pl/index.php?option=com_content\&view=article\&id=2744:rewolucja-1905-krytyka-polityczna-a-departament-gier\&catid=20:recenzje-gier-planszowych\&Itemid=119.

Rewolucja 1905 r. - dlaczego rewolucja została zapomniana? https://audycje.tokfm.pl/podcast/ Rewolucja-1905-r-dlaczego-rewolucja-zostala-zapomniana-W-Ogrodzie-Powszechnym-rozmawiaja-prof-Piotr-Laskowski-i-Karolina-Lewicka/64201.

Rewolucja 1905 - historia (nie)zapomniana, https://www.youtube.com/watch?v=NytVdUKQjKA.

Rewolucja 1905 roku. Przewodnik Krytyki Politycznej, red. K. Piskała, W. Marzec, Warszawa 2013.

Ruch zawodowy w Polsce: zarys dziejów, t. 1: 1869-1918, oprac. J. Kancewicz [i in.], red. S. Kalabiński, Warszawa 1974.

Sapoznikov P., The Revolutionary Movement in Kobrin 1904-1905, w: Book of Kobrin; the scroll of life and destruction, eds. B. Shwartz, I.C. Bil(e)tzki, transl. N. Avidan, A. Perry, San Francisco 1992, s. 135-141.

Sekura A., Rewolucyjni Mściciele. Śmierć z browningiem w ręku, Poznań 2010.

Shanin T., Revolution as a Moment of Truth, New Haven 1986.

Sikorska-Kowalska M. „Wolność czy zbrodnia?” Rewolucja 1905-1907 roku w Łodzi na łamach gazety „Rozwój”, Łódź 2012.

Słownik biograficzny działaczy polskiego ruchu robotniczego, red. nacz. F. Tych, t. 1-3, Warszawa 1978-1992.

Sowa J., Fantomowe ciało króla. Peryferyjne zmagania z nowoczesna forma, Kraków 2011.

Sowa J., Inna Rzeczpospolita jest możliwa! Widma przeszłości, Warszawa 2014.

Szabat B., Kielce i kielczanie w czasie rewolucji 1905-1907 roku, Kielce 2009.

Szwarc A., Rewolucja 1905 roku na ziemiach polskich. Refleksje o historiografii i postawach inteligenckich elit, „Artes Liberales. Zeszyty Naukowe Wyższej Szkoły Humanistycznej im. Aleksandra Gieysztora" (2006), nr 1, s. 25-36.

Świat należy nie tylko objaśniać, ale i przekształcać... Rozmowa z profesorem dr. hab. Jerzym Damroszem, „Rocznik Towarzystwa Naukowego Płockiego” (2014), nr 6, s. 494-507.

Waingertner P., Najnowsza ksiażka Wiktora Marca. Socjolog, filozof i historyk o rewolucji 1905 roku, „Kronika Miasta Łodzi” (2016), nr 4 (76), s. 199-203.

Waingertner P., Zet wobec Narodowej Demokracji w przededniu I wojny światowej, „Acta Universitatis Lodziensis. Folia Historica" (1998), nr 63, s. 161-173.

Weeks T., Rebelia i reakcja: Rewolucja 1905 roku i plebejskie doświadczenie polityczne. By Wiktor Marzec [recenzja], „Slavic Review” (2017) no. 4(76), s. 1082-1083. 
Wiktor Marzec [hasło], https://hse-ru.academia.edu/WiktorMarzec.

Wójcik A., Wpływ partii politycznych na kształtowanie świadomości społecznej i narodowej na Lubelszczyźnie na przełomie XIX i XX wieku, „Acta Universitatis Lodziensis. Folia Historica" (1992), nr 45, s. 111-118.

Zackiewicz G., Syndykalizm w polskiej refleksji i rzeczywistości politycznej I połowy XX wieku, Kraków 2013.

Żarnowska A., Spojrzenie na rewolucje 1905 r. w polskiej historiografii - garść refleksji, „Kwartalnik Historyczny" 63 (2006), nr 4, s. 59-94.

Анархисты. Документы и материалы, т. 1: 1883-1916, ред. О.В. Волобуев, сост. авт. пред., введ. и комм. В.В. Кривенький, Москва 1998.

Бунд: Документы и материальы. 1894-1921 г2., сост. и авт. коммент. Ю. Амиантов [и др.], Москва 2010.

Буховец О.Г., Социальные конфликты и крестьянская ментальность в Российской империи начала ХХ века. Новые материаль, методы, результаты, Москва 1996.

Власть и общество в Первой российской революиии 1905-1907 г2. Документальные свидетельства, сост., ред. и предисл. А.П. Ненароков, П.Ю. Савельев, отв. ред. А.А. Чернобаев, Москва 2017.

Генкин И., По тюрьмам и этапам, Петербург 1922.

Дмовский Р., Германия, Россия и польский вопрос, ред. Д.С. Буневич, Г.В. Холодов, пер. с пол. А.Ю. Баженова, Санкт-Петербург 2017.

Киржниц А.Д., 1905. Еврейское рабочее движение. Обзор, материаль и документьи, Москва-Ленинград 1928.

Конеи, крепостничества в России (документы, письма, мемуары, статьи), сост., общ. ред., вст. ст. и коммент. В.А. Федоров, Москва 1994.

Ланевский А.И., Актриса второго плана: память о революиии 1905-1907 г2. в Польше, w: 80 лет Великой Испанской революиии: память, люди, уроки (Прямухинские чтения 2016), ред. С.Г. Корнилов [и др.], Москва 2017, s. 189-217.

Левандовский А., На заре жизни, „Каторга и ссылка” (1931), nr 4 (77), s. 106-107.

Павлов С., Опьт первой революиии. Россия. 1900-1907, Москва 2008.

Первое мая в иарской России. 1890-1916 г2. Сборник документов, общ. ред. О. Чаадаева, Москва 1939.

Россия в 1905-1907 г2.: энциклопедия, отв. ред. В.В. Журавлев [и др.], Москва 2016.

Шанин Т., Революиия как момент истины. Россия 1905-1907 г2. - 1917-1922 г2., Москва 1997.

Aleksander Łaniewski, dr nauk humanistycznych w zakresie historii, adiunkt w Pracowni Historii Europy Wschodniej i Studiów nad Imperiami XIX i XX wieku IH PAN. Obszar zainteresowań: historia anarchizmu, rewolucja 1905 roku, pamięć historyczna lewicy, najnowsza historia Białorusi, polityka historyczna na Białorusi (alexandr.iwanowicz@gmail.com).

Aleksander Laniewski, PhD in History, assistant professor at the Section for the History of Eastern Europe and the Empires of the $19^{\text {th }}$ and $20^{\text {th }}$ Centuries at the Tadeusz Manteuffel Institute of History Polish Academy of Sciences. Specialisation: history of anarchism in Eastern Europe in the $20^{\text {th }}$ century, the 1905 Revolution, the issue of memory in the left-wing movements, recent socio-political history of Belarus, politics of memory in Belarus (alexandr. iwanowicz@gmail.com). 